\title{
‡USGS
}

science for a changing world

\section{Geophysical Studies in the Vicinity of Blue Mountain and Pumpernickel Valley near Winnemucca, North- Central Nevada}

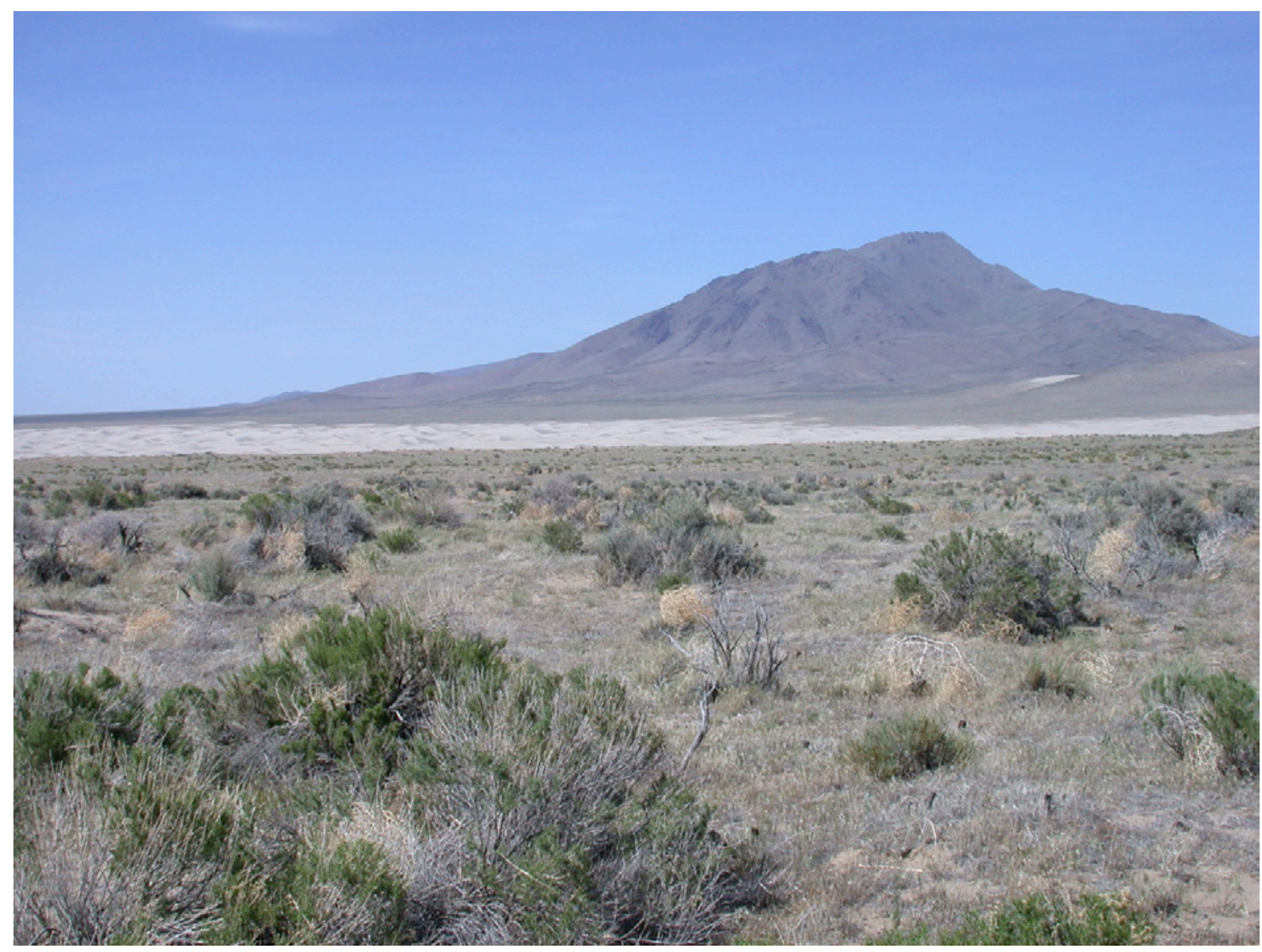

Open-File Report 2012-1207

U.S. Department of the Interior

U.S. Geological Survey 
Cover: Blue Mountain, Nev. View southeastward. 


\section{Geophysical Studies in the Vicinity of Blue Mountain and Pumpernickel Valley near Winnemucca, North- Central Nevada}

By David A. Ponce

Open-File Report 2012-1207

U.S. Department of the Interior

U.S. Geological Survey 


\section{U.S. Department of the Interior \\ KEN SALAZAR, Secretary}

\section{U.S. Geological Survey \\ Marcia K. McNutt, Director}

\section{U.S. Geological Survey, Reston, Virginia 2012}

For more information on the USGS - the Federal source for science about the Earth, its natural

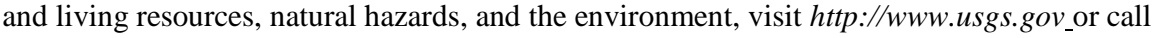
1-888-ASK-USGS

For an overview of USGS information products, including maps, imagery, and publications, visit http://www.usgs.gov/pubprod

Suggested citation:

Ponce, D.A., 2012, Geophysical studies in the vicinity of Blue Mountain and Pumpernickel Valley near Winnemucca, north-central Nevada: U.S. Geological Survey Open-File Report 2012-1207, 14 p.

Any use of trade, product, or firm names is for descriptive purposes only and does not imply endorsement by the U.S. Government.

Although this report is in the public domain, permission must be secured from the individual copyright owners to reproduce any copyrighted materials contained within this report. 


\section{Contents}

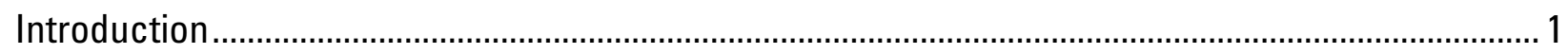

Gravity, Magnetic, and Physical-Property Data ........................................................................ 1

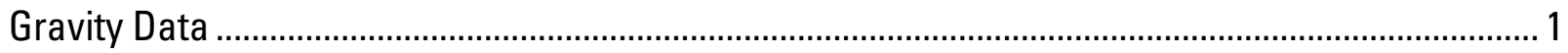

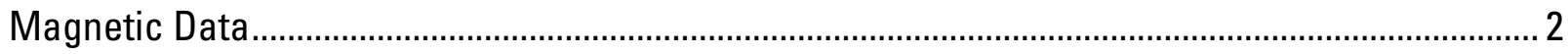

Physical-Property Data …………………………………………………………………. 3

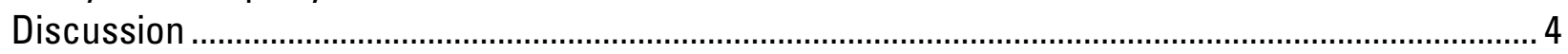

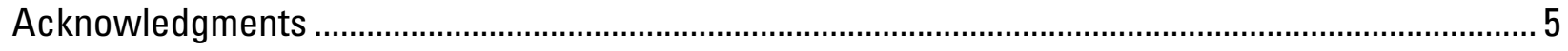

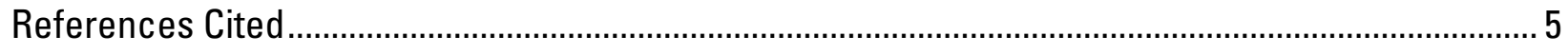

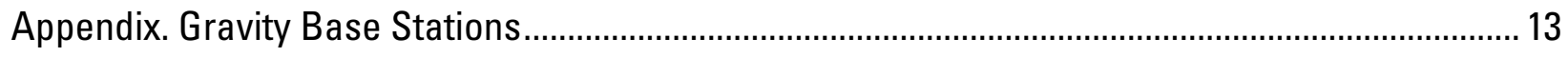

\section{Figures}

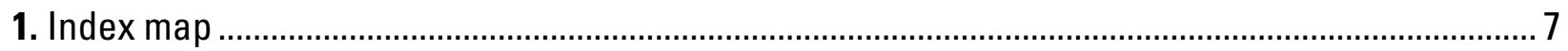

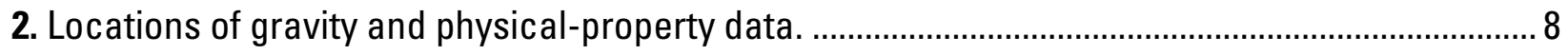

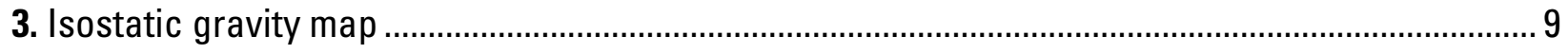

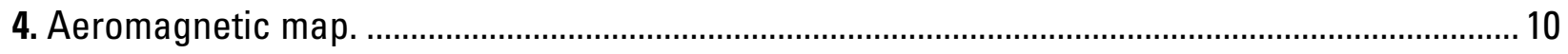

5. Location of truck-towed magnetic profiles. ................................................................................. 11

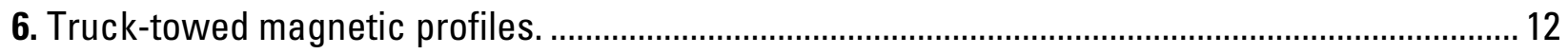

\section{Tables}

1. Gravity data, format, and description of codes ...............................................t1_gravity_data.xls

2. Truck-towed magnetic data t2_truck_mag_data.xls

3. Physical-property data, format, and rock types. .t3_rock_property_data.xls

4. Summary of selected physical property data by rock type 
This page intentionally left blank. 


\title{
Geophysical Studies in the Vicinity of Blue Mountain and Pumpernickel Valley near Winnemucca, North- Central Nevada
}

\author{
By David A. Ponce ${ }^{1}$
}

\section{Introduction}

From May 2008 to September 2009, the U.S. Geological Survey (USGS) collected data from more than 660 gravity stations, 100 line-km of truck-towed magnetometer traverses, and 260 physicalproperty sites in the vicinity of Blue Mountain and Pumpernickel Valley, northern Nevada (fig. 1). Gravity, magnetic, and physical-property data were collected to study regional crustal structures as an aid to understanding the geologic framework of the Blue Mountain and Pumpernickel Valley areas, which in general, have implications for mineral- and geothermal-resource investigations throughout the Great Basin.

\section{Gravity, Magnetic, and Physical-Property Data}

\section{Gravity Data}

Gravity data, which were collected between May 2008 and September 2009, consist of records from more than 660 new stations concentrated in areas of sparse control, as well as along traverses of interest (fig. 2). All the gravity data were tied to a primary base station at the Winnemucca airport (WIN, Jablonski, 1974) and a secondary base station established at the Winnemucca courthouse (WINCH); both base stations are described in the appendix. Gravity stations were located between approximately lat $40^{\circ} 40^{\prime}$ and $41^{\circ} 30^{\prime} \mathrm{N}$. and long $117^{\circ} 00^{\prime}$ and $118^{\circ} 45^{\prime} \mathrm{W}$. and are distributed across parts of the Vya, McDermitt, Lovelock, and Winnemucca $1^{\circ}$ x $2^{\circ}$ (1:250,000 scale) USGS topographic-quadrangle maps.

New gravity data were reduced by using standard methods (Blakely, 1995) and include the following corrections: (1) an earth-tide correction, which corrects for tidal effects of the Moon and Sun; (2) an instrument-drift correction, which compensates for drift in the instrument's spring; (3) a latitude correction, which accounts for variation in the Earth's gravity with latitude; (4) free-air correction, which accounts for the variation in gravity due to elevation relative to sea level; (5) a Bouguer correction, which corrects for the attraction of material between the station and sea level; (6) a curvature correction, which corrects the Bouguer correction for the effect of the Earth's curvature; (7) a terrain correction, which removes the effect of topography to a radial distance of $167 \mathrm{~km}$ from the station; and (8) an isostatic correction, which removes long-wavelength variations in the gravity field related to the compensation of topographic loads.

LaCoste and Romberg gravity meter G614 and a Scintrex CG-5 gravity meter were used in this survey. Gravity meter readings were converted to gravity units for LaCoste and Romberg gravity meter G614 by using factory calibration constants, as well as a secondary calibration factor (1.00036) determined by multiple gravity readings over the Mount Hamilton calibration loop east of San Jose, Calif. (Barnes and others, 1969). For the Scintrex CG-5 gravity meter, the factory meter-calibration constant was also checked and redetermined over the Mount Hamilton calibration loop. Observed

\footnotetext{
${ }^{1}$ U.S. Geological Survey, 345 Middlefield Road, Menlo Park, CA 94025, ponce@usgs.gov, http://geomaps.wr.usgs.gov/gump/.
} 
gravity values were based on a time-dependent linear drift between successive base readings and referenced to the International Gravity Standardization Net 1971 (IGSN 71) gravity datum (Morelli, 1974, p. 18). Free-air gravity anomalies were calculated by using the Geodetic Reference System 1967 formula for theoretical gravity on the ellipsoid (International Union of Geodesy and Geophysics, 1971, p. 60) and Swick's (1942, p. 65) formula for the free-air correction. Bouguer, curvature, and terrain corrections were added to the free-air anomaly to determine the complete Bouguer anomaly at a standard reduction density of 2,670 kg/m³. Finally, a regional isostatic gravity field was removed from the Bouguer field by assuming an Airy-Heiskanen model for isostatic compensation of topographic loads (Jachens and Roberts, 1981), with an assumed nominal sea-level crustal thickness of $25 \mathrm{~km}$, a crustal density of $2,670 \mathrm{~kg} / \mathrm{m}^{3}$, and a density contrast across the base of the crust of $400 \mathrm{~kg} / \mathrm{m}^{3}$. Gravity values are expressed in milligal ( $\mathrm{mGal}$ ), a unit of acceleration or gravitational force per mass equal to $10^{-5} \mathrm{~m} / \mathrm{s}^{2}$.

Station locations and elevations were obtained by using a Trimble GeoXH differential Global Positioning System (GPS) instrument. The GeoXH receiver uses the Wide Area Augmentation System (WAAS) which, in combination with a base station and postprocessing with a Continually Operated Reference Station (CORS), results in submeter vertical accuracy.

Terrain corrections, which account for the variation in topography near a gravity station, were calculated using a combination of manual and digital methods. Terrain corrections consist of a three-part process: an innermost or field-terrain correction, an innerzone-terrain correction, and an outerzoneterrain correction. The innermost-terrain correction, which was estimated in the field, extends from the station to a radial distance of $68 \mathrm{~m}$ and is equivalent to the outer radius of Hayford and Bowie's (1912) zone B. The innerzone-terrain correction, which was estimated from a digital elevation model (DEM) with 10- or 30-m resolution derived from USGS 7.5' topographic maps, extends from $68 \mathrm{~m}$ to a radial distance of $2 \mathrm{~km}$ (D. Plouff, unpub. data, 2006). The outerzone-terrain correction, which was calculated by using a DEM derived from USGS 1:250,000-scale topographic maps and an automated procedure based on geographic coordinates (Plouff, 1966; Plouff, 1977; Godson and Plouff, 1988), extends from 2 $\mathrm{km}$ to a radial distance of $167 \mathrm{~km}$. Digital terrain corrections were calculated by computing the gravity effect of each grid cell in the DEM, using the distance and difference in elevation of each grid cell from the gravity station.

New gravity data were combined with preexisting gravity data (Ponce, 1997) from the surrounding area in Nevada (fig. 2). All gravity data were gridded by using a minimum curvature algorithm at an interval of $500 \mathrm{~m}$ and displayed on a color-contoured isostatic gravity map (fig. 3). Observed gravity values are accurate to about $0.05 \mathrm{mGal}$, and calculated gravity anomalies to about 0.5 mGal. Principal facts of new gravity data are listed in table 1 in an Excel workbook.

\section{Magnetic Data}

\section{Aeromagnetic Data}

Aeromagnetic data were derived from a State-wide compilation for Nevada (Kucks and others, 2006) and displayed with a 0.5-km grid on a color-contoured aeromagnetic map (fig. 4). The aeromagnetic data for the state of Nevada were compiled and adjusted by Kucks and others (2006) for diurnal variations in the Earth's magnetic field, either upward or downward continued, if necessary, to a flightline elevation of $305 \mathrm{~m}$ above the ground, leveled, adjusted to a common datum, and merged to produce a uniform map that allows interpretations across survey boundaries.

In general, the aeromagnetic data in the study area (fig. 4) are of poor to fair resolution. Most coverage of the study area consists of surveys flown at a high barometric elevation of 2,700 m, with flightlines oriented east-west and spaced 1.6 to $3.2 \mathrm{~km}$ apart. Although the flightline spacing and, in general, high flightline elevation of some of these original surveys used in the State-wide compilation 
may not resolve some magnetic sources lying at shallow depths beneath the surface, the effect is negligible at the scale of our investigations.

\section{Truck-Towed Magnetic Data}

About 100 line-km of truck-towed magnetometer data (figs. 5,6) was collected along Jungo Road (line 1, fig. 5) and selected traverses on the west side of Blue Mountain, a known gold deposit and geothermal area (fig. 5). Magnetic and GPS data were collected simultaneously at 1-s intervals, using a Geometrics G858 Ce-vapor magnetometer attached to an aluminum carriage connected to the vehicle by aluminum tubing and towed about $9 \mathrm{~m}$ behind the vehicle. The height of the magnetometer above the ground surface was about $2 \mathrm{~m}$. A portable Geometrics G856 proton-precession base-station magnetometer located just south of Blue Mountain was used to record diurnal variations in the Earth's magnetic field during the truck-towed magnetometer surveys.

During field operations, truck-towed magnetic data were recorded and viewed in real time, using Geometrics MagLog software. Raw magnetic data were downloaded and processed by using Geometrics MagMap2000 software, where magnetometer and GPS data were merged. The location of the magnetometer was recorded by using a Trimblenonmagnetic Ag132 GPS receiver mounted on an aluminum frame attached to the magnetometer. The receiver has real-time differential-correction capabilities with an Omnistar satellite system, resulting in submeter horizontal accuracy. Diurnal variations recorded by the base-station magnetometer were removed, and the data were edited to remove cultural "noise", such as passing cars, culverts, fences, and powerlines. The locations of truck-towed magnetic traverses are shown in figure 5, magnetic profiles are plotted in figure 6, and the data are listed in table 2 in an Excel workbook. In general, the accuracy of the magnetometer is about 1 nanoteslas (nT). The data are presented as geographic coordinates (NAD83 datum) and magnetic-field values (in nT).

\section{Physical-Property Data}

Rock samples were collected from outcrops throughout the study area and from two cores from drillholes DB-1 and DB-2 at Blue Mountain. Drill-hole data were previously reported by Ponce and others (2009). Additional data are listed in table 3, in an Excel workbook, and a summary of selected density and magnetic susceptibility measurements by rock type is listed in table 4. Digital data include station identifier, geographic coordinates (NAD27), rock type, density, and magnetic susceptibility. Densities were determined by the buoyancy method, and weights were measured on an electronic balance with an accuracy of $\pm 0.01 \mathrm{~g}$. Magnetic susceptibility was measured with a Kappameter model KT-5 with an accuracy of 0.01 x10-3 SI unit. Grain, saturated-bulk, and dry-bulk densities were calculated for each sample by weighing the sample in air $\left(W_{a}\right)$, saturated and submerged in water $\left(W_{w}\right)$, and saturated and weighed in air (Was), using the following formulas, where all weights are measured in grams:

$$
\begin{aligned}
& \text { Grain density }=1,000 \mathrm{~kg} / \mathrm{m}^{3} * W_{a} /\left(W_{a}-W_{w}\right), \\
& \text { Saturated-bulk density }=1,000 \mathrm{~kg} / \mathrm{m}^{3} * W_{a s} /\left(W_{a s}-W_{w}\right) \text {, and } \\
& \text { Dry-bulk density }=1,000 \mathrm{~kg} / \mathrm{m}^{3} * W_{a} /\left(W_{a s}-W_{w}\right) .
\end{aligned}
$$


Table 4. Summary of selected physical-property data by rock type.

\begin{tabular}{|c|c|c|c|c|c|c|c|c|c|c|c|c|c|c|}
\hline \multirow{2}{*}{$\begin{array}{l}\text { Rock } \\
\text { type }\end{array}$} & \multirow{2}{*}{$\begin{array}{c}\text { Number } \\
\text { of }\end{array}$} & \multirow{3}{*}{$\begin{array}{l}\text { Grain } \\
\text { density } \\
\mathrm{kg} / \mathrm{m}^{3}\end{array}$} & \multicolumn{2}{|c|}{ Range } & \multirow{2}{*}{$\begin{array}{l}\text { Saturated- } \\
\text { bulk density }\end{array}$} & \multicolumn{3}{|c|}{ Range } & \multirow{3}{*}{$\begin{array}{c}\text { Dry-bulk } \\
\text { density } \\
\text { kg/m³ }\end{array}$} & \multicolumn{2}{|c|}{ Range } & \multirow{3}{*}{$\begin{array}{c}\text { Magnetic } \\
\text { susceptibility } \\
\text { x10 }\end{array}$} & \multicolumn{2}{|c|}{ Range } \\
\hline & & & & & & & & & & & & & & \\
\hline & samples & & & & $\mathrm{kg} / \mathrm{m}^{3}$ & & & & & & & & & \\
\hline \multicolumn{15}{|l|}{ Granitic Rocks } \\
\hline Granite & 6 & 2658 & 2624 & - 2683 & 2627 & 2548 & - & 2664 & 2608 & 2501 & -2653 & 5.20 & 0.15 & 9.75 \\
\hline Granodiorite & 83 & 2670 & 2560 & - 2777 & 2629 & 2527 & & 2757 & 2604 & 2475 & - 2745 & 4.80 & 0.11 & - 14.6 \\
\hline Diorite & 82 & 2814 & 2613 & -2930 & 2777 & 2566 & & 2913 & 2756 & 2495 & -2905 & 9.54 & 0.10 & -28.4 \\
\hline Gabbro & 3 & 2871 & 2866 & -2878 & 2860 & 2855 & & 2863 & 2854 & 2850 & -2858 & 8.28 & 6.39 & -10.5 \\
\hline \multicolumn{15}{|l|}{ Volcanic Rocks } \\
\hline Basalt & 2 & 2496 & 2496 & - 2497 & 2420 & 2401 & & 2440 & 2369 & 2336 & - 2402 & 1.94 & 1.87 & 2.0 \\
\hline Tuff & 5 & 2608 & 2572 & -2643 & 2512 & 2437 & & 2589 & 2452 & 2351 & -2565 & 0.06 & 0.04 & 0.09 \\
\hline \multicolumn{15}{|l|}{ Sedimentary Rocks } \\
\hline Argillite & 4 & 2705 & 2655 & -2766 & 2668 & 2628 & & 2709 & 2647 & 2610 & 2676 & 0.08 & 0.01 & 0.17 \\
\hline Mudstone & 7 & 2645 & 2522 & - 2733 & 2610 & 2454 & & 2717 & 2588 & 2409 & -2708 & 0.11 & 0.05 & 0.21 \\
\hline Metasediment & 13 & 2721 & 2602 & - 2923 & 2688 & 2563 & & 2906 & 2668 & 2537 & 2897 & 0.19 & 0.02 & 0.42 \\
\hline Slate & 5 & 2708 & 2661 & -2782 & 2647 & 2560 & & 2725 & 2611 & 2499 & -2694 & 0.10 & 0.07 & 0.18 \\
\hline
\end{tabular}

\section{Discussion}

In general, once gravity data are reduced to isostatic gravity anomalies, they reflect lateral density variations in the mid to upper crust. Thus, gravity anomalies can be used to infer the subsurface structure of known or unknown geologic features provided a density contrast occurs across the geologic boundaries. Gravity anomalies can, for example, reveal variations in lithology and delineate such features as calderas, deep sedimentary basins, and faults, all of which play an important role in defining the geologic framework of a given area.

An isostatic gravity map of the study area (fig. 3) is dominated by a series of gravity highs and lows that generally reflect dense pre-Cenozoic outcrops and low-density basin fill, respectively. The gravity highs that occur over Blue Mountain, the Slumbering Hills, the Bloody Run Hills, the Eugene Mountains, and the East Range reflect relatively denser Paleozoic rocks and Triassic to Jurassic metasedimentary rocks. Relatively lower-amplitude gravity highs over parts of the Slumbering Hills and the Bloody Run Hills probably reflect lower-density plutonic rocks that compose the central parts of the ranges and extend to some depth (figs. 1,2). The lowest gravity values reflect moderately deep sedimentary basins in Desert, Silver State, Grass, Paradise, and Pumpernickel Valleys. On the basis of the amplitudes of these gravity lows, these basins reach depths of about $2 \mathrm{~km}$, which is typical of most basins in Nevada.

Magnetic anomalies, which reflect changes in the Earth's magnetic field are generally used to infer lateral variations in rock magnetization. In general, the magnetic anomalies observed throughout the study area (fig. 1) are explainable by variations in exposed rock types and their magnetic properties. Short-wavelength, high-amplitude magnetic anomalies are generally caused by volcanic rocks that are moderately to strongly magnetic. Owing to the dipolar nature of magnetic sources, magnetic highs (or lows) are typically accompanied by an associated magnetic low (or high), whereas isolated magnetic lows, may be associated with altered volcanic rocks or weakly magnetic silicic and sedimentary rocks.

The aeromagnetic map of the study area (fig. 4) is dominated by broad, long-wavelength, highamplitude anomalies associated with moderately magnetic plutonic rocks mapped throughout the area (Stewart and Carlson, 1978). High-amplitude, short-wavelength anomalies, such as in the northwest corner of the map, are associated with volcanic rocks. Magnetic anomalies are particularly useful for delineating the subsurface extent of plutonic rocks because plutons are commonly more magnetic than the basement rocks they intrude. For example, the pluton in the central block of the Slumbering Hills 
may extend well beyond the range and beneath Desert Valley. In addition to these features, the prominent arcuate aeromagnetic anomalies referred to as the western and central Northern Nevada Rifts (NNRW, NNRC, figs. 1,4), that are similar to the Northern Nevada Rift (NNRE; inset, fig. 1) east of Winnemucca, reflect crustal-scale mafic-dike intrusions that occurred during the inception of the Yellowstone Hotspot (Zoback and others, 1994; Ponce and Glen, 2002). Indeed, the mafic dike swarm along the west flank of Blue Mountain (Wyld, 2002; Ponce and others, 2010), with its associated aeromagnetic anomaly and its better defined truck-borne magnetic anomaly (figs. 4-6), is the surface manifestation of one of these rift zones.

The diverse physical properties of the rocks that underlie the study area (fig. 1) are well suited to geophysical investigations. The contrasts in density and magnetic properties between pre-Cenozoic crystalline basement and the overlying Tertiary volcanic rocks and unconsolidated alluvium, for example, produce a distinctive pattern of gravity and magnetic anomalies that can be used to infer subsurface geologic structure and aid in understanding the geologic framework and geothermal potential of northern Nevada.

\section{Acknowledgments}

We thank Bob Morin and Janet Watt for their assistance in collecting or processing gravity, truck-towed magnetic, and physical property data. We thank Nevada Geothermal Power for granting access to their properties and especially John Casteel and Kim Niggeman who helped facilitate our efforts. We also thank Bruce Chuchel and Vicki Langenheim of the USGS for their reviews and George Havach and Carolyn Donlin for editing the report.

\section{References Cited}

Barnes, D.F., Oliver, H.W., and Robbins, S.L., 1969, Standardization of gravimeter calibrations in the Geological Survey: Eos, American Geophysical Union Transactions, v. 50, no. 10, p. 626-627.

Blakely, R.J., 1995, Potential theory in gravity and magnetic applications: New York, Cambridge University Press, 441 p.

Godson, R.H., and Plouff, D., 1988, BOUGUER version 1.0, a microcomputer gravity-terrain-correction program: U.S. Geological Survey Open-File Report 88-644-A, 22 p.

[http://pubs.er.usgs.gov/publication/ofr88644A accessed October 10, 2012]

Hayford, J.F., and Bowie, W., 1912, The effect of topography and isostatic compensation upon the intensity of gravity: U.S. Coast and Geodetic Survey Special Publication 10, 132 p.

International Union of Geodesy and Geophysics, 1971, Geodetic reference system 1967: International Association of Geodesy Special Publication 3, 116 p.

Jablonski, H.M., 1974, World relative gravity reference network North America, Parts 1 and 2, with a supplementary section on IGSN 71 gravity datum values (rev. ed.): U.S. Defense Mapping Agency Aerospace Center Reference Publication 25, 1261 p.

Jachens, R.C., and Roberts, C.W., 1981, Documentation of a FORTRAN program, ‘isocomp', for computing isostatic residual gravity: U.S. Geological Open-File Report 81-574, 26 p.

[http://pubs.er.usgs.gov/publication/ofr81574, accessed October 10, 2012].

Kucks, R.P., Hill, P.L., and Ponce, D.A., 2006, Nevada magnetic and gravity maps and data-a website for the distribution of data: U.S. Geological Survey Data Series 234

[http://pubs.usgs.gov/ds/2006/234, accessed April 13, 2012].

Morelli, C., ed., 1974, The International Gravity Standardization Net 1971: International Association of Geodesy Special Publication 4, 194 p.

Plouff, D., 1966, Digital terrain corrections based on geographic coordinates [abs.]: Geophysics, v. 31, no. 6, p. 1208. 
Plouff, D., 1977, Preliminary documentation for a FORTRAN program to compute gravity terrain corrections based on topography digitized on a geographic grid: U.S. Geological Survey OpenFile Report 77-535, 45 p. [http://pubs.er.usgs.gov/publication/ofr77535, accessed October 10, 2012].

Ponce, D.A., 1997, Gravity data of Nevada: U.S. Geological Survey Digital Data Series DDS-42, 27 p., CD-ROM. [http://pubs.usgs.gov/dds/dds-42/, accessed October 10, 2012].

Ponce, D.A., and Glen, J.M.G, 2002, Relationship of epithermal gold deposits to large-scale fractures in northern Nevada: Economic Geology, v. 97, no. 1, p. 3-9.

Ponce, D.A., Glen, J.M.G., Watt, J.T., and Casteel, J., 2010, Geophysical setting of the Blue Mountain geothermal area, north-central Nevada and its relationship to a crustal-scale fracture associated with the inception of the Yellowstone Hotspot: Geothermal Resources Council Transactions, v. 34, p. 881-885.

Ponce, D.A., Watt, J.T., Casteel, J., and Logsdon, G., 2009, Physical-property measurements on core samples from drill-holes DB-1 and DB-2, Blue Mountain geothermal prospect, north-central Nevada: U.S. Geological Survey Open-File Report 2009-1022, 18 p. [http://pubs.usgs.gov/of/2009/1022/, accessed October 10, 2012].

Swick, C.A., 1942, Pendulum gravity measurements and isostatic reductions: U.S. Coast and Geodetic Survey Special Publication 232, 82 p.

Stewart, J.H., and Carlson, J.E., 1978, Geologic map of Nevada: U.S. Geological Survey and Nevada Bureau of Mines and Geology, scale 1:500,000.

Wyld, S.J., 2002, Structural evolution of a Mesozoic backarc fold-and-thrust belt in the U.S. Cordillera; new evidence from northern Nevada: Geological Society of America Bulletin, v. 114, no. 11, p. 1452-1468.

Zoback, M.L., McKee, E.H., Blakely, R.J., and Thompson, G.A., 1994, The northern Nevada rift; regional tectono-magmatic relations and middle Miocene stress direction: Geological Society of America Bulletin, v. 106, p. 371-382. 


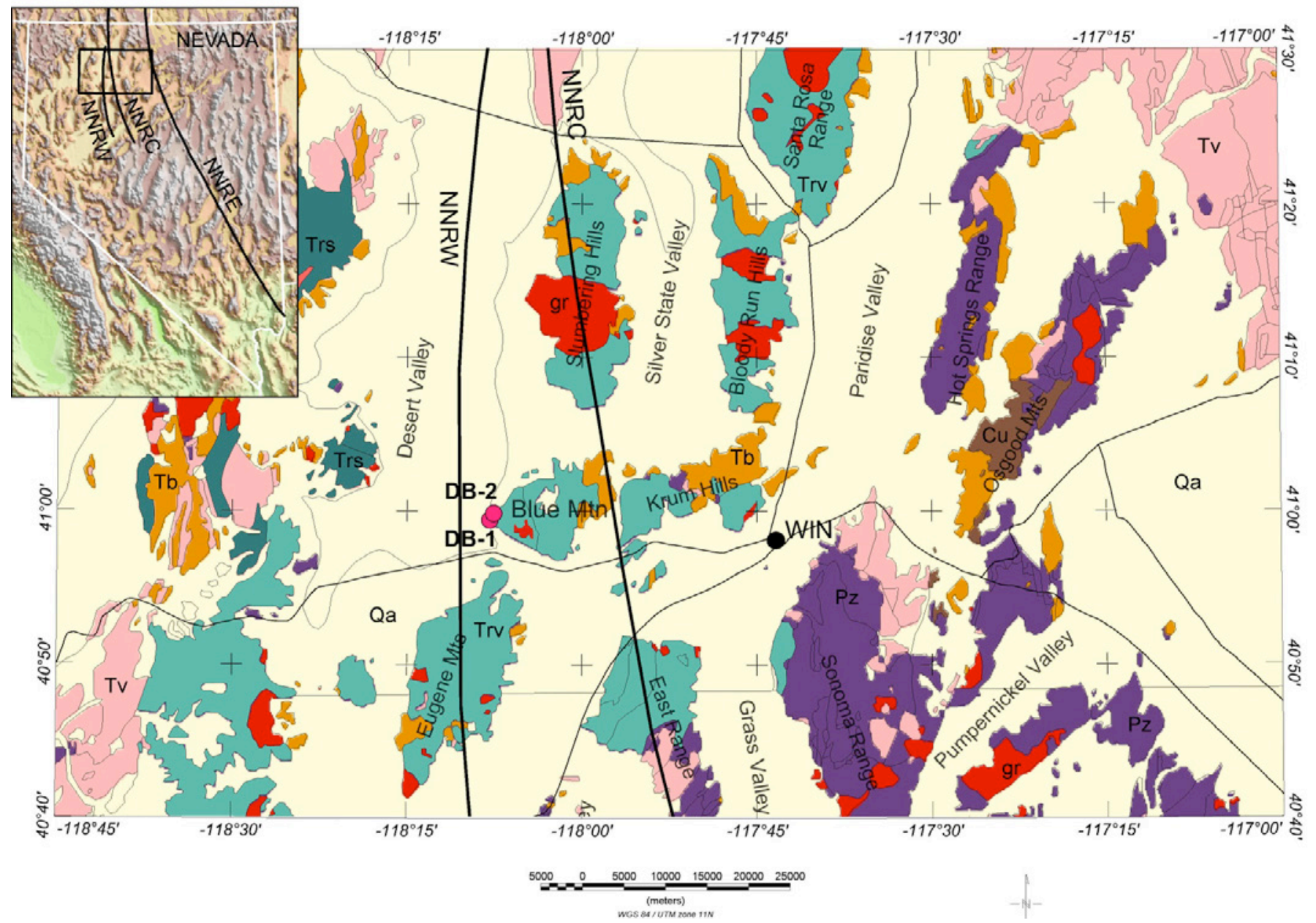

Figure 1. Index and simplified geologic map of Winnemucca and vicinity (from Stewart and Carlson, 1978). The stock mapped in the western part of Blue Mountain is now considered to be a mafic dike swarm (Wyld, 2002; Ponce and others, 2010). DB-1, DB-2, drill holes on west side of Blue Mountain; NNRW, NNRC, NNRE, western, central, and eastern Northern Nevada Rifts (Ponce and Glen, 2002); WIN, Winnemucca. Geology: yellow, Quaternary alluvium (Qa); pink, Tertiary volcanic rocks (Tv); orange, Tertiary basalt (Tb); red, undivided granitic plutons (gr); forest green, Triassic metasediments (Trs); green, Triassic volcanic rocks (Trv); purple, undivided Paleozoic rocks (Pz); brown, Cambrian rocks (Cu). 


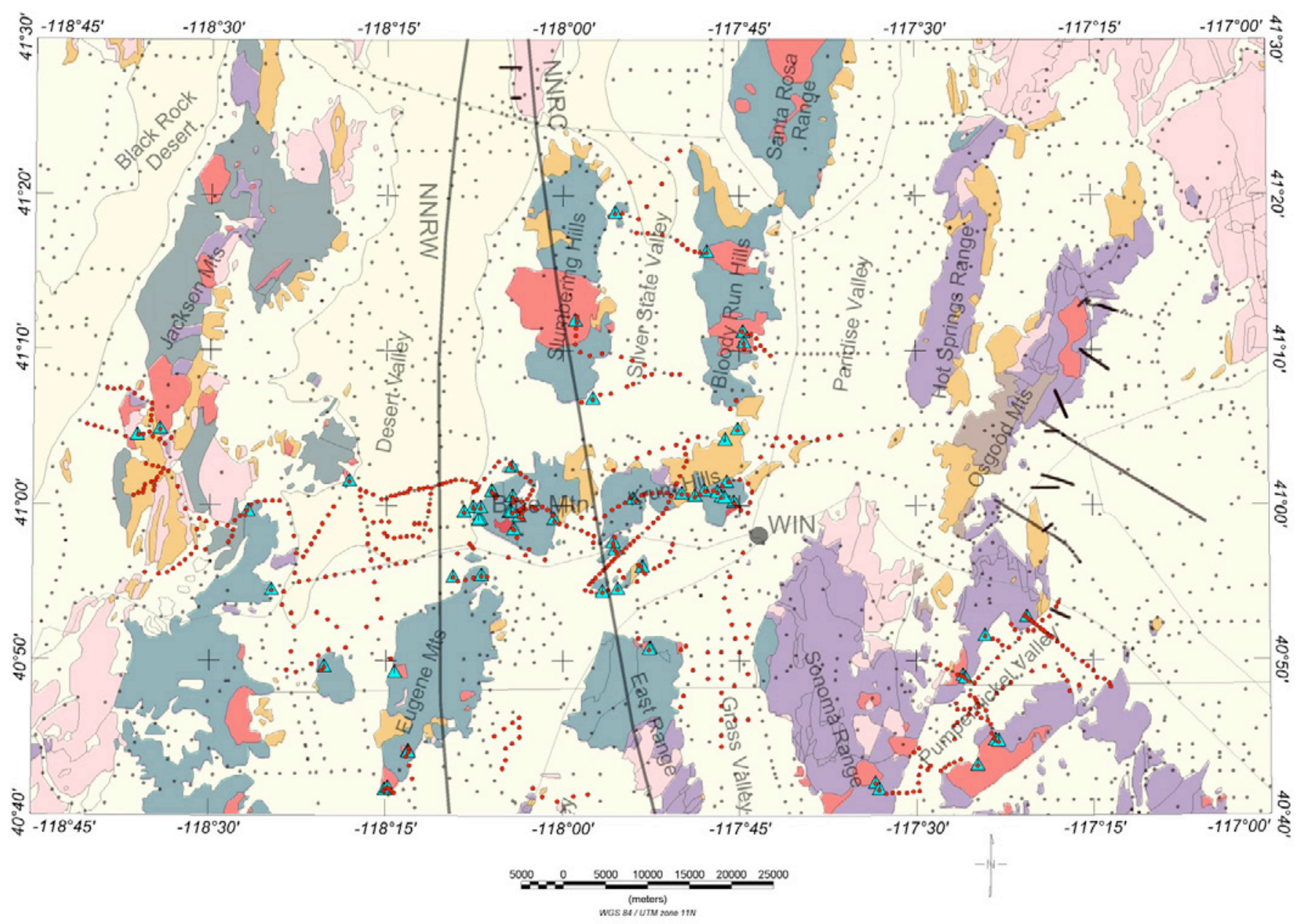

Figure 2. Locations of gravity and physical property data in the study area. Red circles, gravity stations collected during this study; gray circles, pre-existing gravity stations (Ponce, 1997); blue triangles, physical property locations. See figure 1 for explanation. 


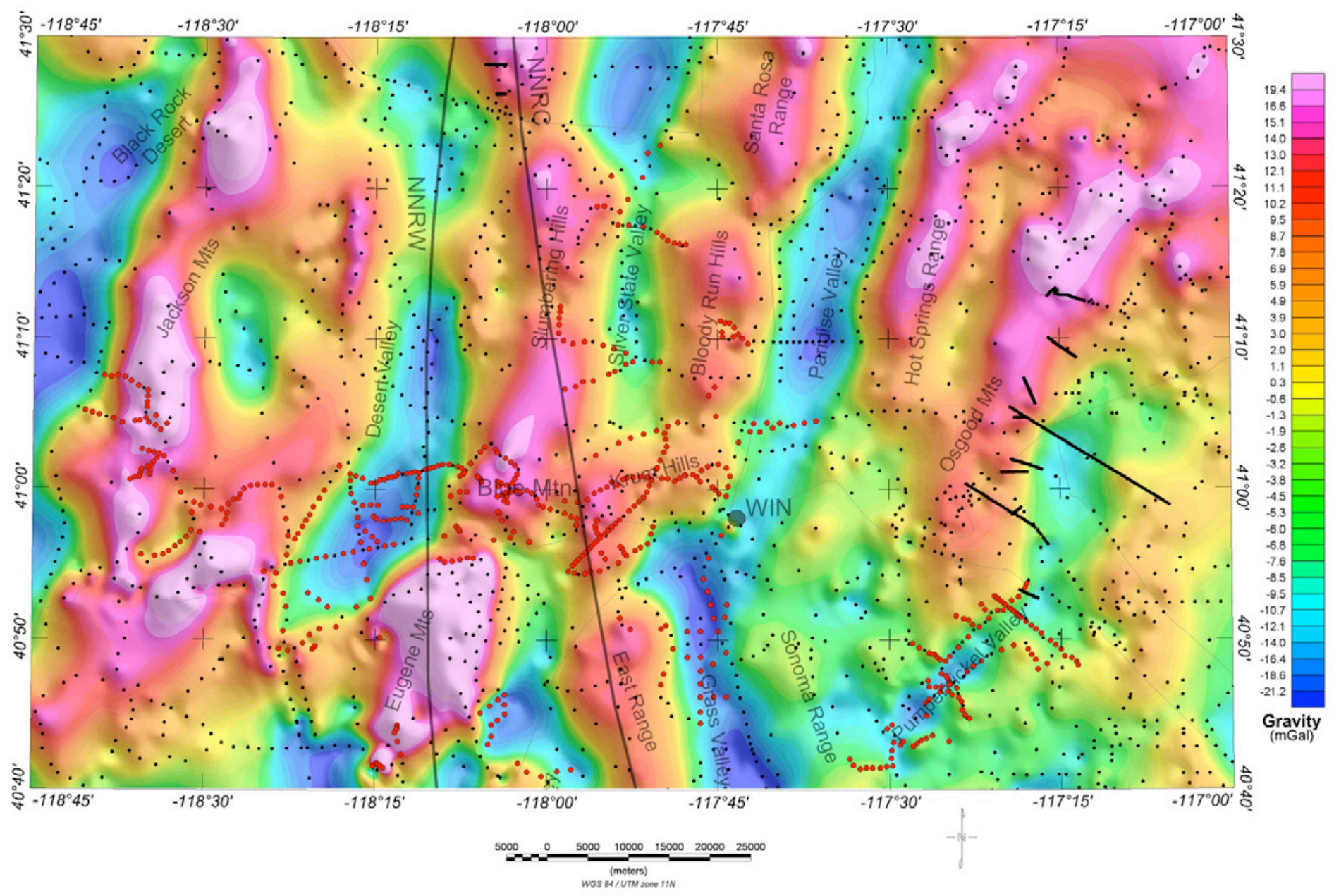

Figure 3. Isostatic gravity map of the study area. See figures 1 and 2 for explanation. 


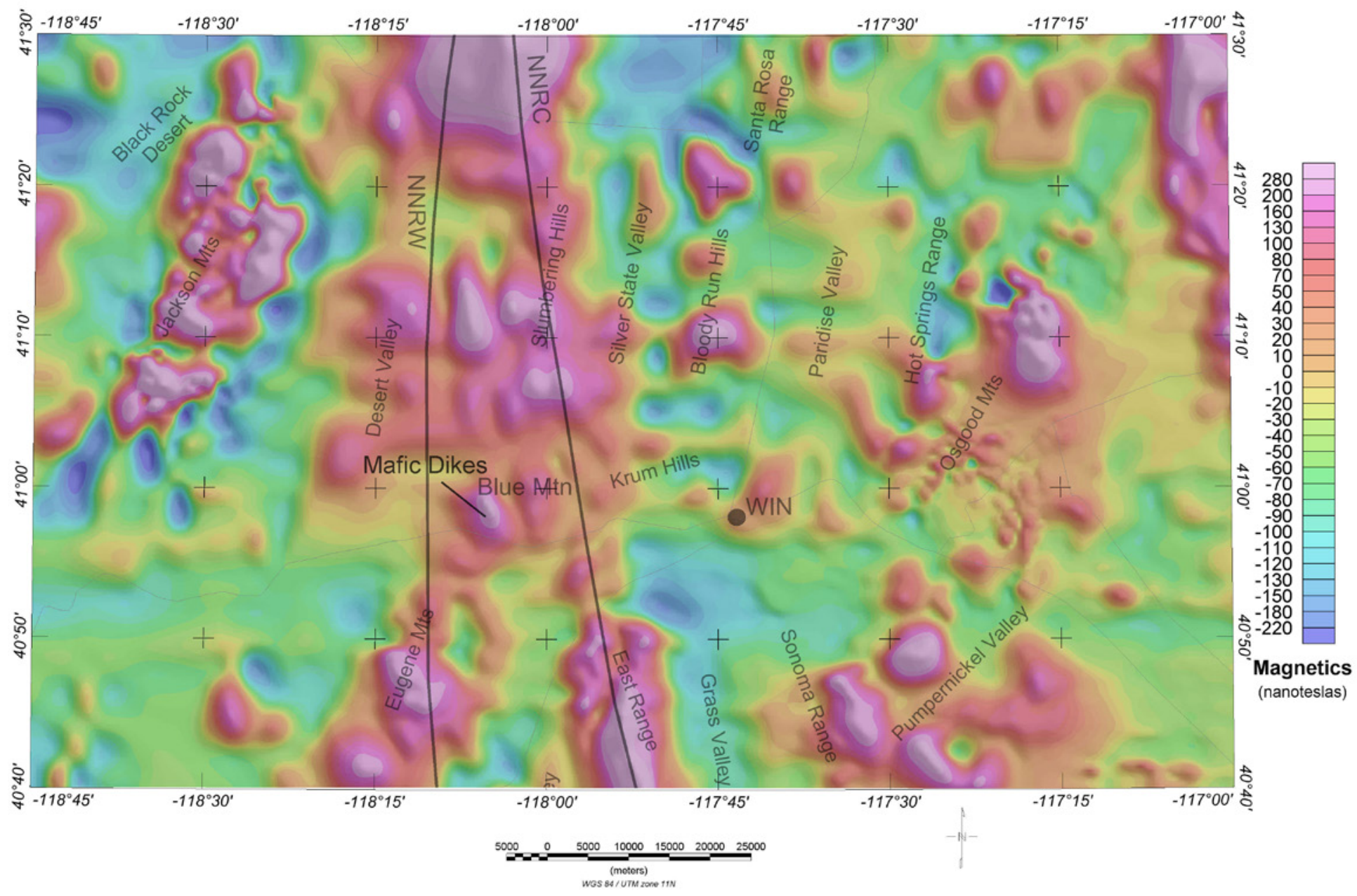

Figure 4. Aeromagnetic map of the study area showing location of NNR's and mafic dike swarm at Blue Mountain. See figure 1 for explanation. 


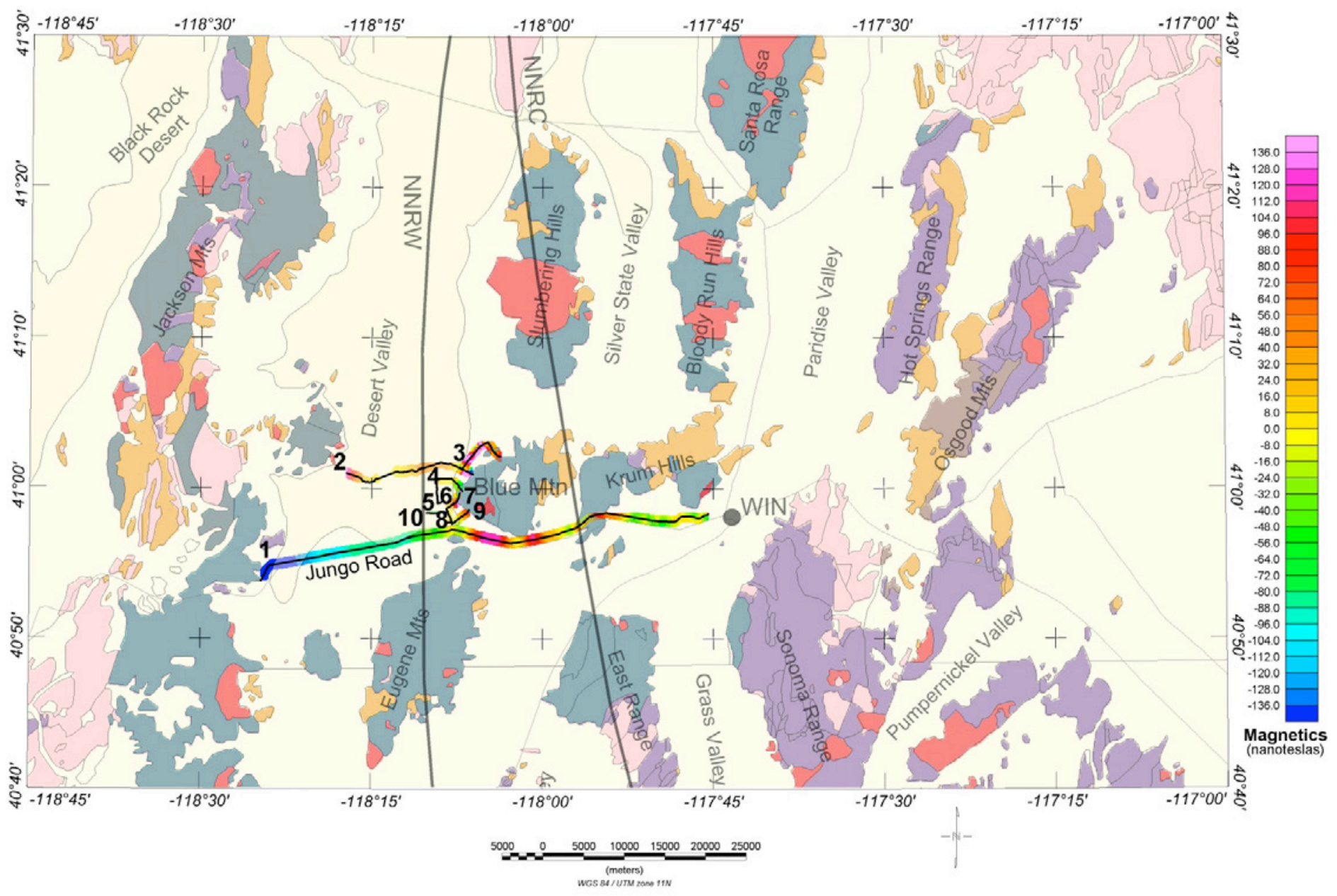

Figure 5. Location of truck-towed magnetic traverses 1 through 10 (black lines) near Blue Mountain and their magnetic anomalies. See figure 1 for explanation. 

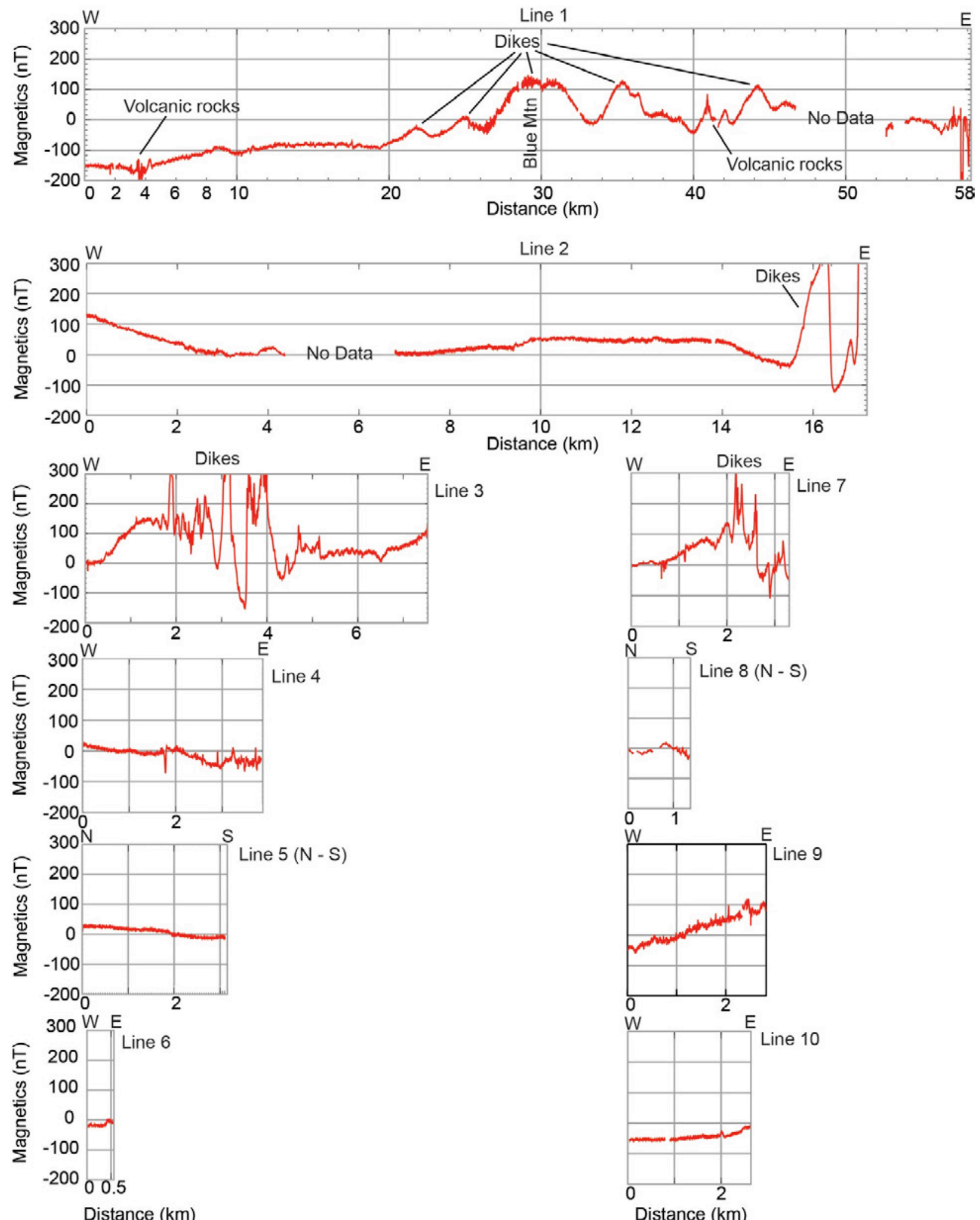

Figure 6. Truck-towed magnetic profiles near Blue Mountain. Vertical scale is the same for all profiles. Horizontal scales are the same, except for Line 1 which is at $1 / 3$ the scale. Profiles are from west to east, except for Lines 5 and 8 which are from north to south. 


\section{Appendix. Gravity Base Stations}

GRAVITY BASE STATION

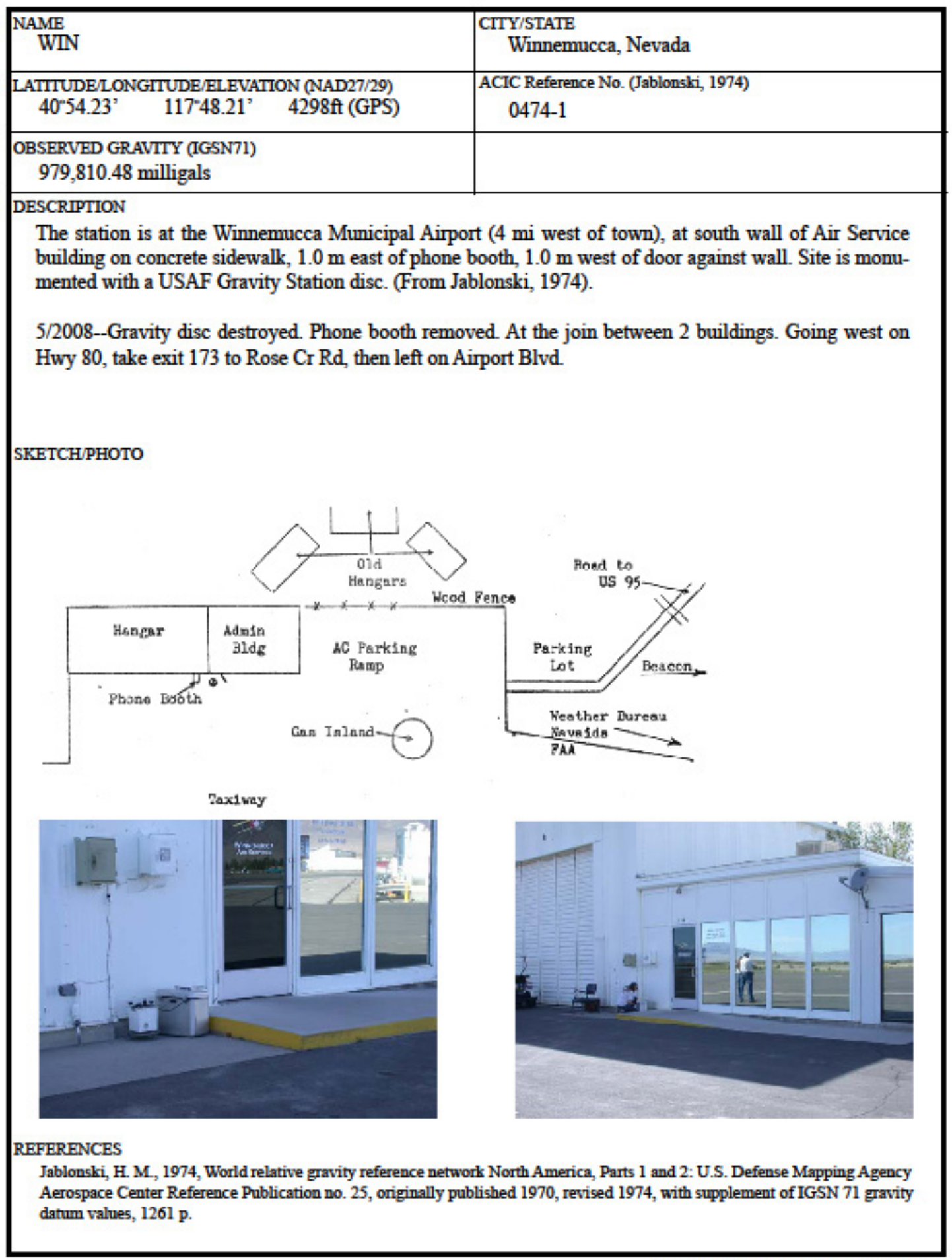

David A. Ponce, U.S. Geological Survey 
GRAVITY BASE STATION

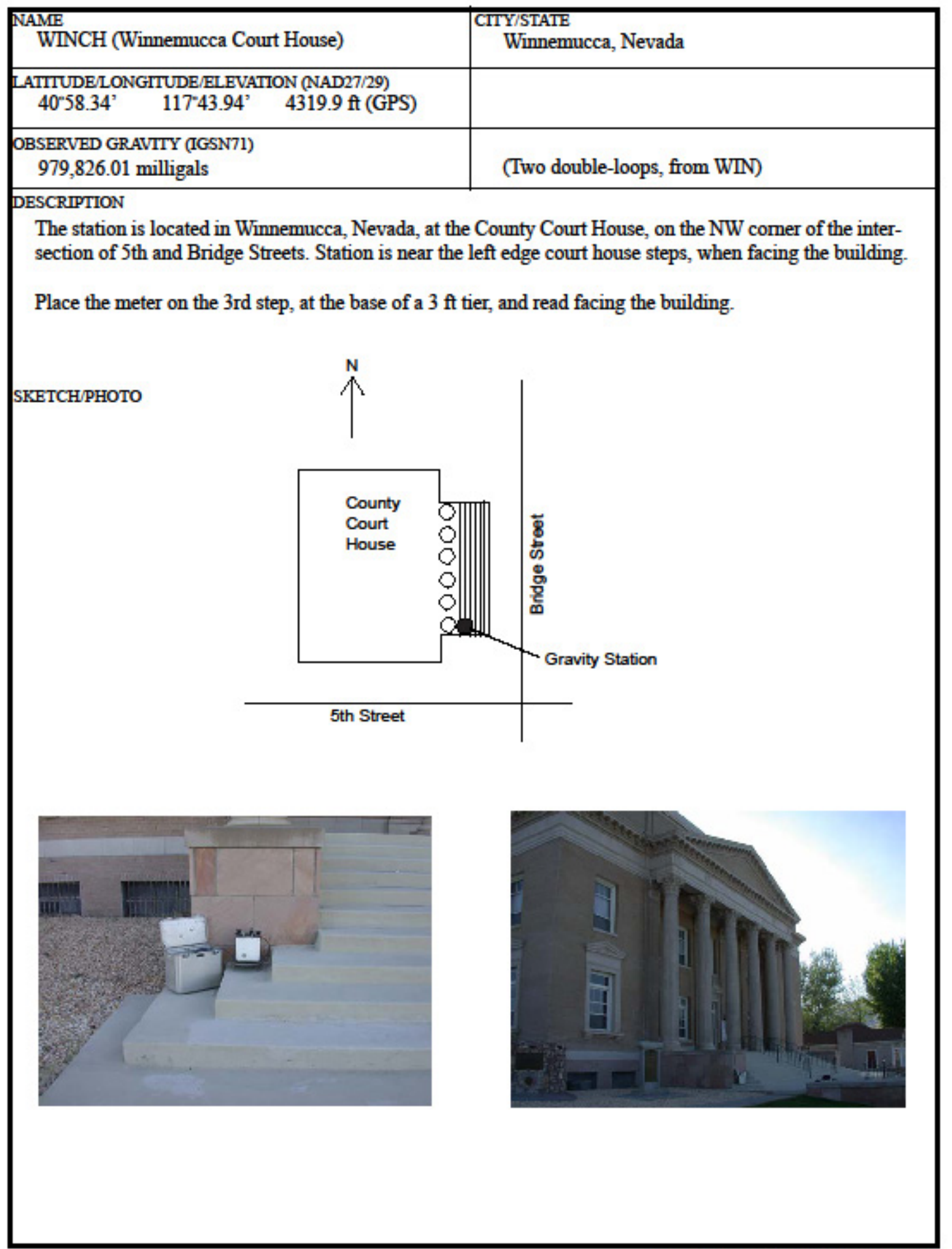

David A. Ponce, U.S. Geological Survey 